\title{
Use of chemical cues by coral reef animal larvae for habitat selection
}

\author{
David Lecchini ${ }^{1,2, *}$, Yohei Nakamura ${ }^{3}$ \\ ${ }^{1}$ USR 3278 CNRS-EPHE, CRIOBE, 98729 Moorea, French Polynesia \\ ${ }^{2}$ Laboratoire d'Excellence 'CORAIL', 98729 Moorea, French Polynesia \\ ${ }^{3}$ Graduate School of Kuroshio Science, Kochi University, 7838502 Kochi, Japan
}

\begin{abstract}
The present study explored the importance of chemical cues for habitat selection by fish (6 species), crustacean (1 species), and cephalopod (1 species) larvae in a 4 -channel choice flume at Ishigaki Island, Japan. The larval attraction toward chemical cues from reef patches (seagrass bed patch, live coral patch, dead coral patch, and control water; Expt 1) and microhabitats within a given reef patch (live coral colonies, dead coral colonies, seagrass, and conspecifics; Expt 2) was tested in a 4-channel choice flume. The results in Expt 1 showed that 3 fish species used chemical cues to move significantly towards reef patches: Chromis viridis toward live coral patch water and Lutjanus fulviflamma and L. gibbus toward seagrass bed patch water. In Expt 2, 6 of 8 species (4 fishes, 1 cephalopod, and 1 crustacean) used chemical cues to move significantly toward conspecific water (Apogon properuptus, C. viridis, Dascyllus reticulatus, L. fulviflamma, Octopus cyanea, and Palaemonidae sp.). Overall, these results suggest that marine species can actively select settlement habitats according to olfactory cues (more specially, cues from conspecifics). Moreover, these results highlight the importance of conspecific cues over other types of information (reef patch and microhabitat) for habitat selection. Social aggregation of fish, crustacean, and cephalopod larvae with older conspecifics may be the result of individuals using conspecific 'guides' to potentially find beneficial resources (availability of resources and low mortality).
\end{abstract}

KEY WORDS: Sensory mechanisms $\cdot$ Settlement cues $\cdot$ Fish $\cdot$ Crustacean $\cdot$ Cephalopod

\section{INTRODUCTION}

The majority of cephalopod, fish, and crustacean species on coral reefs have a life cycle that includes a dispersive planktonic larval phase (ocean) followed by a sedentary reef phase (lagoon). The replenishment and persistence of most coral reef species are contingent on dispersing larvae identifying a habitat and becoming established in this habitat (Leis et al. 2011). Because it is unlikely that successful habitat selection by coral reef animals at settlement is solely a matter of chance (Doherty 2002), one of the greatest challenges faced by a marine species with pelagic larval stages is how to re-locate the relatively rare patches of suitable coral reef habitat on which they settle and ultimately reside as adults (Arvedlund \& Kavanagh 2009).

Accomplishing successful recruitment necessitates, at a range of spatial scales, identifying (1) an island or a continental shelf within the boundless oceanic matrix, (2) an appropriate reef patch within this island or this continental shelf, and (3) a suitable microhabitat and conspecifics within this patch (Lecchini \& Galzin 2003). Some studies have highlighted the visual, chemical, and/or acoustic abilities of marine larvae (particularly fish and crustaceans) to recognize an island or a continental shelf (e.g. Gerlach et al. 2007, Dixson et al. 2008, Stanley et al. 2012), a suitable reef 
patch (e.g. Montgomery et al. 2006, Huijbers et al. 2008, Lecchini et al. 2013), a suitable recruitment microhabitat (e.g. Munday et al. 2009, Igulu et al. 2011, Devine et al. 2012), predators (Dixson et al. 2012), or conspecifics (e.g. Lecchini et al. 2010, Lecchini 2011).

For example 1 (island or continental shelf detection), Leis \& Carson-Ewart (2003) have shown that fish larvae orientate themselves toward or away from an island when they are at least $1000 \mathrm{~m}$ away. For 2 (reef patch detection), Huijbers et al. (2008) reported that settling fish larvae are capable of olfactory discrimination and prefer the odor of their home reef (mangroves and seagrass beds versus coral reefs). For 3 (microhabitat or conspecific detection), Lecchini et al. (2010) showed that crustacean larvae made active habitat choices among the microhabitats tested (live coral, dead coral, macroalgae, and sand), and these species distinguished between their preferred microhabitat versus another habitat and between conspecifics and heterospecifics, using visual and/or olfactory cues.

Despite these recent studies on sensory cues used by marine larvae to select a habitat, the sensory and behavioral mechanisms by which larvae disperse and return from their oceanic phase to adult reef habitats are still not known, particularly for cephalopods (Montgomery et al. 2006, Arvedlund \& Kavanagh 2009, Leis et al. 2011). Moreover, almost all fish studies have focused on the use of a single cue in isolation and at 1 spatial scale (Leis et al. 2011). In the present study, the importance of chemical cues for habitat selection by marine fish, crustacean, and cephalopod larvae was explored at 2 spatial scales, reef patches within coral reefs, and microhabitats or conspecifics within reef patches, at Ishigaki Island (Ryukyu Archipelago, Japan).

Specifically, we tested larval attraction of marine species toward chemical cues from (1) reef patches (seagrass bed patch, live coral patch, dead coral patch, and control water) and (2) microhabitats within a given reef patch (live coral colonies, dead coral colonies, seagrass, and conspecifics) in a 4-channel choice flume.

\section{MATERIALS AND METHODS}

\section{Study area}

The study was conducted on Yoshihara Reef $\left(24^{\circ}\right.$ $\left.27^{\prime} \mathrm{N}, 124^{\circ} 9^{\prime} \mathrm{E}\right)$, Ishigaki Island, southern Ryukyu Islands, Japan. The lagoon (0.5-1.5 m depth depending on the tide, $300 \mathrm{~m}$ wide) was characterized by 3 distinct reef patches from shoreline to ocean (Nakamura et al. 2009a): a seagrass bed dominated by
Cymodocea rotundata, Halodule uninervis, and Thalassia hemprichii (seagrass cover, $96 \pm 6 \%$ ); a dead coral patch dominated by Porites spp. with an algal turf cover $(82 \pm 22 \%)$; and a live coral patch dominated by Acropora spp. $(72 \pm 9 \%)$. Percent cover estimates (mean $\pm \mathrm{SD}$ ) of seagrass, dead coral, and live coral were carried out on each reef patch from 16 replicate $20 \mathrm{~m}$ belt transects using the line transect method (substrate recorded every $1 \mathrm{~m}$ ).

\section{Capture of larvae}

Four light traps were placed on the reef slope at Yoshihara to capture fish, crustacean, and cephalopod larvae just before they entered the lagoon for recruitment (Lecchini et al. 2006, Nakamura et al. $2009 \mathrm{~b})$. The 4 traps were separated by $50 \mathrm{~m}$ and anchored on the reef slope from 17:00 to 08:00 h. Six fish species (Apogon properuptus: 32 larvae captured, Chromis viridis: 37 larvae, Dascyllus reticulatus: 20 larvae, Foa brachygramma: 18 larvae, Lutjanus fulviflamma: 12 larvae, and L. gibbus: 31 larvae), 1 crustacean species (Palaemonidae sp: 28 larvae), and 1 cephalopod species (Octopus cyanea: 19 larvae) were captured in September 2010.

\section{Field observations of the species tested}

Diurnal underwater visual surveys were conducted at Yoshihara to relate the aquarium experiments to the observed distribution of newly settled fish, crustaceans, and cephalopods in the field. The presence or absence of 8 target species (tested in aquaria) were recorded along 16 transects of $20 \times 1 \mathrm{~m}$ on each reef patch (patches of live coral, dead coral, and seagrass bed). Furthermore, we identified the microhabitats on which the newly settled individuals recruited and examined whether they lived in a school or alone (see Table 1). For example, newly settled Chromis viridis and Dascyllus reticulatus were restricted to live Acropora colonies with conspecifics on the live coral patch. However, no newly settled Palaemonidae sp. and Octopus cyanea individuals were recorded at Yoshihara, presumably because of their cryptic and nocturnal life histories.

\section{Chemical detection abilities of marine larvae}

The marine larvae captured during the night with light traps were transferred in aquaria $(0.8 \times 0.5 \times$ 
$0.4 \mathrm{~m})$ by car to the laboratory and subsequently maintained in aquaria $(0.3 \times 0.3 \times 0.2 \mathrm{~m}$; water temperature, $26-27^{\circ} \mathrm{C}$, 1 larva per aquarium) supplied with flow-through ocean seawater without any added artificial or natural habitat and food. Laboratory experiments were performed within $24 \mathrm{~h}$ of larval capture under artificial lighting conditions provided by evenly distributed fluorescent lights (Lecchini et al. 2005, 2013). The larvae were released at Yoshihara Reef after the experiment.

The response of the marine larvae to olfactory cues from the reef patch (Expt 1), microhabitat, or conspecifics (Expt 2) water was tested in a 4-channel choice flume (Fig. 1). Four tanks $(15 \times 15 \mathrm{~cm}$; water depth: $30 \mathrm{~cm}$ ) were simultaneously connected to the 4 upstream channels (A, B, C, and D) of the choice flume $(40 \times 20 \mathrm{~cm}$; water depth: $5 \mathrm{~cm})$ by pipes to create constant gravity-driven flow into each channel at $11 \mathrm{~min}^{-1}$ (flow rate and laminar flow were equal among the 4 channels). In the choice flume, the plastic boundaries between the 4 upstream channels were $10 \mathrm{~cm}$ in length, except between channels B and C (20 cm length). Dye tests showed that a length of $20 \mathrm{~cm}$ between channels $\mathrm{B}$ and $\mathrm{C}$ (in contrast to a length of $10 \mathrm{~cm}$ ) allowed the same laminar flow among the 4 channels and better mixing of the 4 water types in the downstream compartment. Last, as the water hit the back wall in the downstream compartment, eddies were inevitable, which promoted mixing of the 4 water types. Overall, larvae were initially present in the downstream end of the compart-

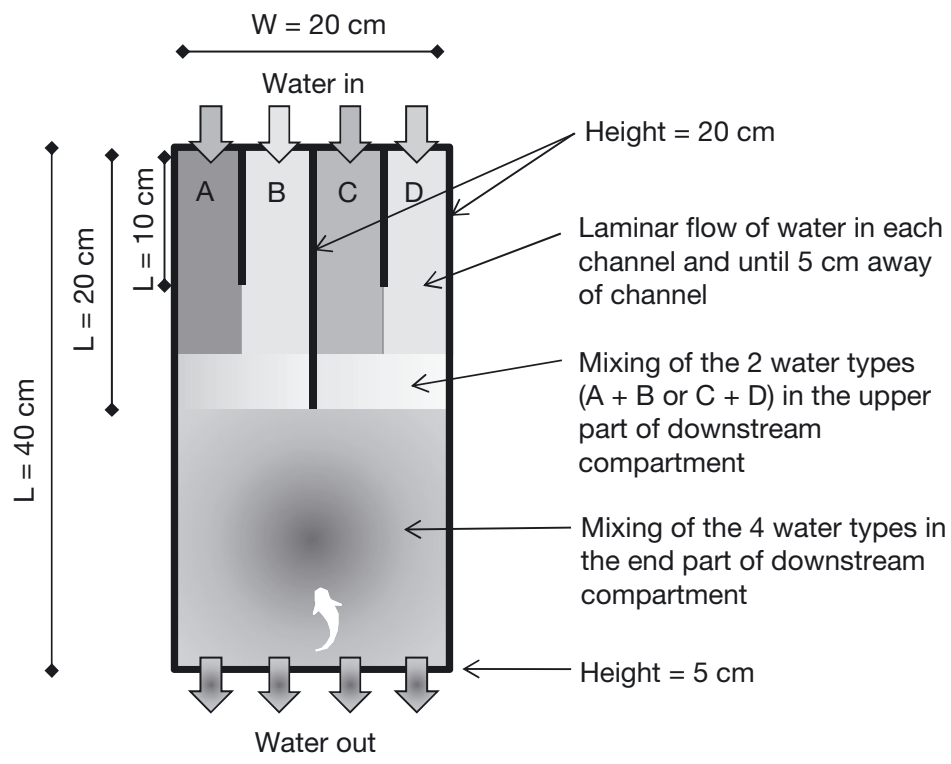

Fig. 1. Four-channel choice flume. Four tanks were simultaneously connected to the 4 upstream channels (A, B, C, and D) by pipes to create constant gravity-driven flow into each channel. See 'Materials and methods' for further details ment where the 4 water types mixed. Movement into the laminar water flow located within $5 \mathrm{~cm}$ of each channel or into the channels themselves was allowed.

A single larva was placed in the center of the downstream end of the choice flume for $1 \mathrm{~min}$ to acclimate before each trial, with a net prohibiting movement of the larva into the upstream channels. Before acclimatization, the flume was filled with filtered ocean seawater. At the start of acclimatization, the 4 different water types were discharged into the flume from each channel. The net was removed after $1 \mathrm{~min}$, and the larva was free to move to either side of the chamber or swim upstream toward the preferred water source.

Preliminary tests showed that larvae swam between channels, and thus must be able to smell all possibilities before making a decision. Marine larvae never made a decision before $34 \mathrm{~s}$. If a larva stayed only in the downstream compartment without moving, this individual was removed from the data. Moreover, preliminary tests showed that if a larva stayed more than $15 \mathrm{~s}$ in one channel, it was considerably attracted by the water from that channel (also see the protocol in Lecchini et al. 2010, 2013).

Therefore, a 'choice' was scored as the first upstream channel in which the larva stayed more than $15 \mathrm{~s}$ (Fig. 1). The trial was complete when the larva remained more than $15 \mathrm{~s}$ in an upstream channel or after a 2 min period (no choice, larva still in downstream compartment or larva still moving between channels). We performed 2 successive experiments with each larva.

Expt 1: Chemical detection abilities of marine larvae for locating reef patches

We determined the distribution of choices exhibited by a larva presented with 4 different water types: (1) live coral patch water, (2) dead coral patch water, (3) seagrass bed patch water, and (4) filtered ocean seawater (control water). Forty liters of water were collected daily between 0.5 and $1 \mathrm{~m}$ depth within each reef patch (patch of live coral, dead coral, or seagrass bed) at Yoshihara Reef. The different seawater types (40 l for each reef patch) were transported in tanks to the laboratory, and marine larvae were tested in the water types within $24 \mathrm{~h}$.

Expt 2: Chemical detection abilities of marine larvae for locating microhabitats or conspecifics

We determined the distribution of choice exhibited by a larva presented with 4 different 
water types: (1) reef patch water in one channel (reef patch that was the most preferred for a given species in Expt 1), (2) microhabitat water in another channel (see next paragraph), (3) conspecific water in another channel (prepared by immersing 5 larvae of the tested species in $2 \mathrm{l}$ of control water for $3 \mathrm{~h}$ ), and (4) control water in the last channel.

Depending on the reef patch most preferred in Expt 1, a microhabitat was chosen for Expt 2: live Acropora colonies from the live coral patch, dead Porites colonies with algal turf cover from the dead coral patch, and seagrass from the seagrass reef patch consisting of a mix of Cymodocea rotundata, Halodule uninervis, and Thalassia hemprichii. The size of the collected microhabitat samples was standardized to a spherical mass with a $3 \mathrm{~cm}$ radius. Thus, if the live coral patch was the most preferred by a given test species in Expt 1, 3 samples of live coral colonies were immersed in 21 of control water for $3 \mathrm{~h}$ to prepare the water for Expt 2. The different microhabitat samples were maintained in aquaria with running ocean seawater. The flume chamber was emptied and washed with fresh water after each trial. The channels containing each water type were randomized after each trial to avoid a confounding effect of the tanks. The larva was maintained in an individual tank for $60 \mathrm{~min}$ before being re-tested to avoid exhausting the larva.

\section{Statistical analysis}

The 'no choice' result (larva stayed in the downstream compartment or larva was still moving between channels) was not included in the analysis (36\% of marine larvae tested in Expt 1 and $17 \%$ in Expt 2), which is standard practice for non-responsive animals in behavioral work (Tolimieri et al. 2004, Huijbers et al. 2012).

A chi-squared test was performed separately for each species and for each experiment to evaluate significant responses to stimuli in trials as deviations from an expected distribution (same number of larvae in each channel). The $p$-value of the chi-squared test must be lower than the $\mathrm{p}_{k}$ value to obtain a significant difference $\left(p_{k}=0.05 / 2=0.025 ; 0.05\right.$ being the probability threshold at $5 \%$ and 2 the number of multiple tests performed with the same data: Expts 1 and 2). This Holm-Bonferroni correction for the significance method prevents cumulative type I error as a result of multiple testing of the same data set.

When significant differences occurred after comparing the number of larvae in the 4 channels, we used the chi-squared test to assess whether the pattern in the channel most chosen by larvae and in the channel filled with control water differed from the null distribution (the preference, given that a 'choice' was made; Lecchini et al. 2007).

\section{RESULTS}

\section{Expt 1: Chemical detection abilities of marine larvae for locating reef patches}

Among the 8 species tested, 3 used chemical cues to move toward the water of the live coral patch or seagrass bed (Fig. 2). The distribution of Chromis viridis, Lutjanus fulviflamma, and L. gibbus larvae differed significantly from the expected distribution $\left(\chi_{3}^{2}=27.5, \mathrm{p}<0.001 ; \chi_{3}^{2}=16.3, \mathrm{p}=0.001 ; \chi_{3}^{2}=10.7\right.$, $\mathrm{p}=0.020$, respectively). Among the 3 reef patches tested, $C$. viridis preferred the live coral patch water over the control water $\left(\chi_{1}^{2}=9.6, p=0.002\right)$, and seagrass bed patch water was preferred by $L$. fulviflamma $\left(\chi_{1}^{2}=6.4, \mathrm{p}=0.012\right)$ and L. gibbus $\left(\chi_{1}^{2}=4.3\right.$, $\mathrm{p}=0.024)$.

The distributions of Dascyllus reticulatus, Foa brachygramma, and Octopus cyanea larvae were not significantly different from their expected distributions $\left(\chi_{3}^{2}<8.7, \mathrm{p}>0.025\right.$; Fig. 2). In contrast, larval distributions of Apogon properuptus and Palaemonidae sp. were significantly different from their expected distributions $\left(\chi_{3}^{2}>12.0, \mathrm{p}<0.025\right)$. However, they did not show specific reef patch water preference over the control water: $50 \%$ of the $A$. properuptus larvae were attracted by the dead coral patch water and $50 \%$ by the control water. Similarly, $45 \%$ of the Palaemonidae sp. larvae were attracted by the live coral patch water and $45 \%$ by the control water.

\section{Expt 2: Chemical detection abilities of marine larvae for locating microhabitats}

Among the 8 species tested, only Foa brachygramma larvae showed no significant attraction $\left(\chi_{3}{ }^{2}=10.0\right.$, $p=0.035$ ). The larval distributions of the other 7 species were significantly different from the expected distribution $\left(\chi_{3}{ }^{2}>11.2, \mathrm{p}<0.025\right)$. Thus, 5 fish species (Apogon properuptus, Chromis viridis, Dascyllus reticulatus, Lutjanus fulviflamma, and L. gibbus), 1 crustacean species (Palaemonidae sp.), and the 1 cephalopod species (Octopus cyanea) used chemical cues to move toward the conspecific or reef patch water (Fig. 3). 


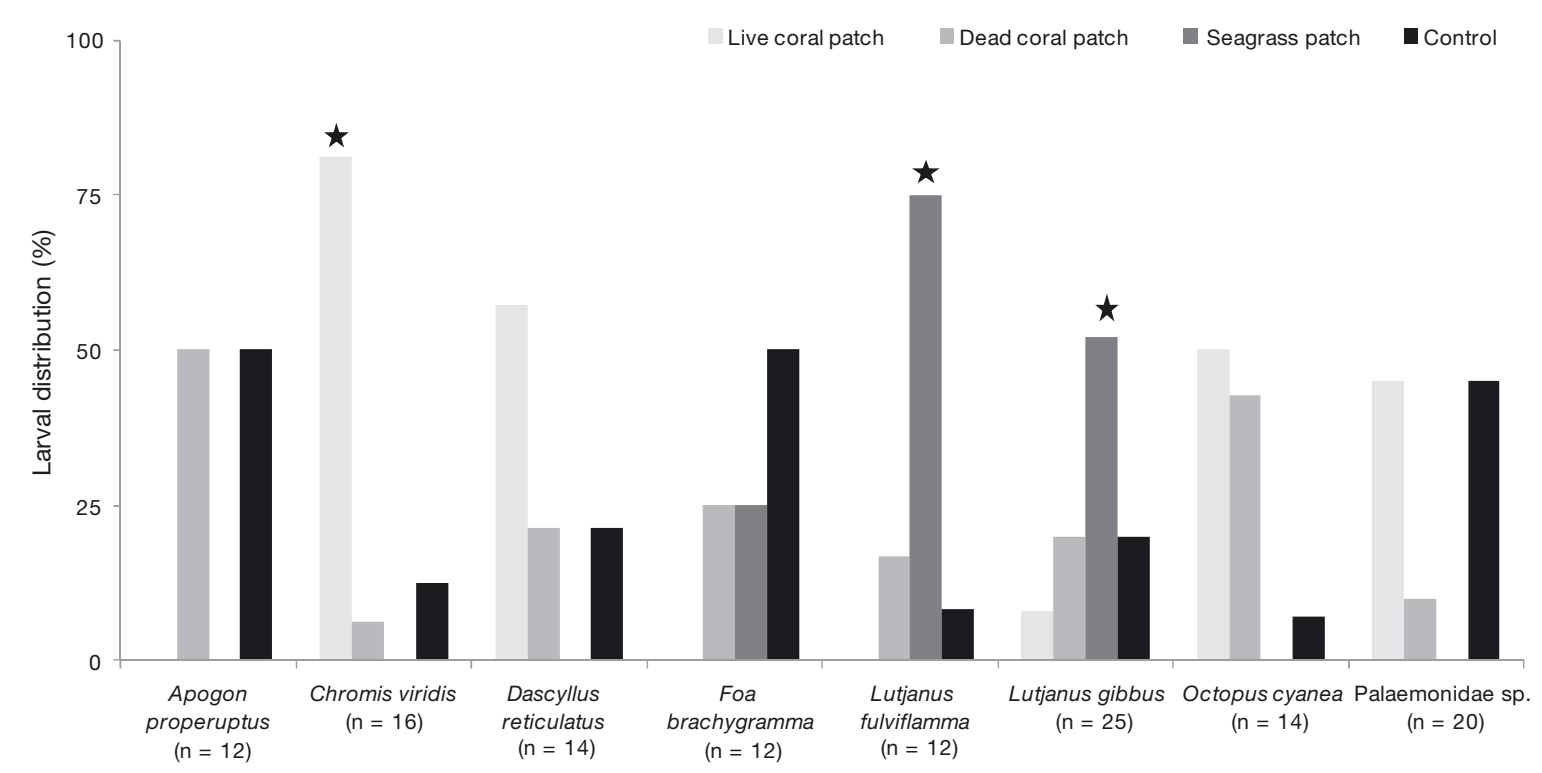

Fig. 2. Larval distribution of the 8 species of coral reef animals among the choice flumes to determine their preference among 3 reef patches (live coral, dead coral, and seagrass bed patches) and control water. The number of larvae analyzed (the no-choice result was not included in statistical analyses) is given below the species name. Stars indicate that p-values were significant for a given species (larval attraction more toward one reef patch water than toward the control water)

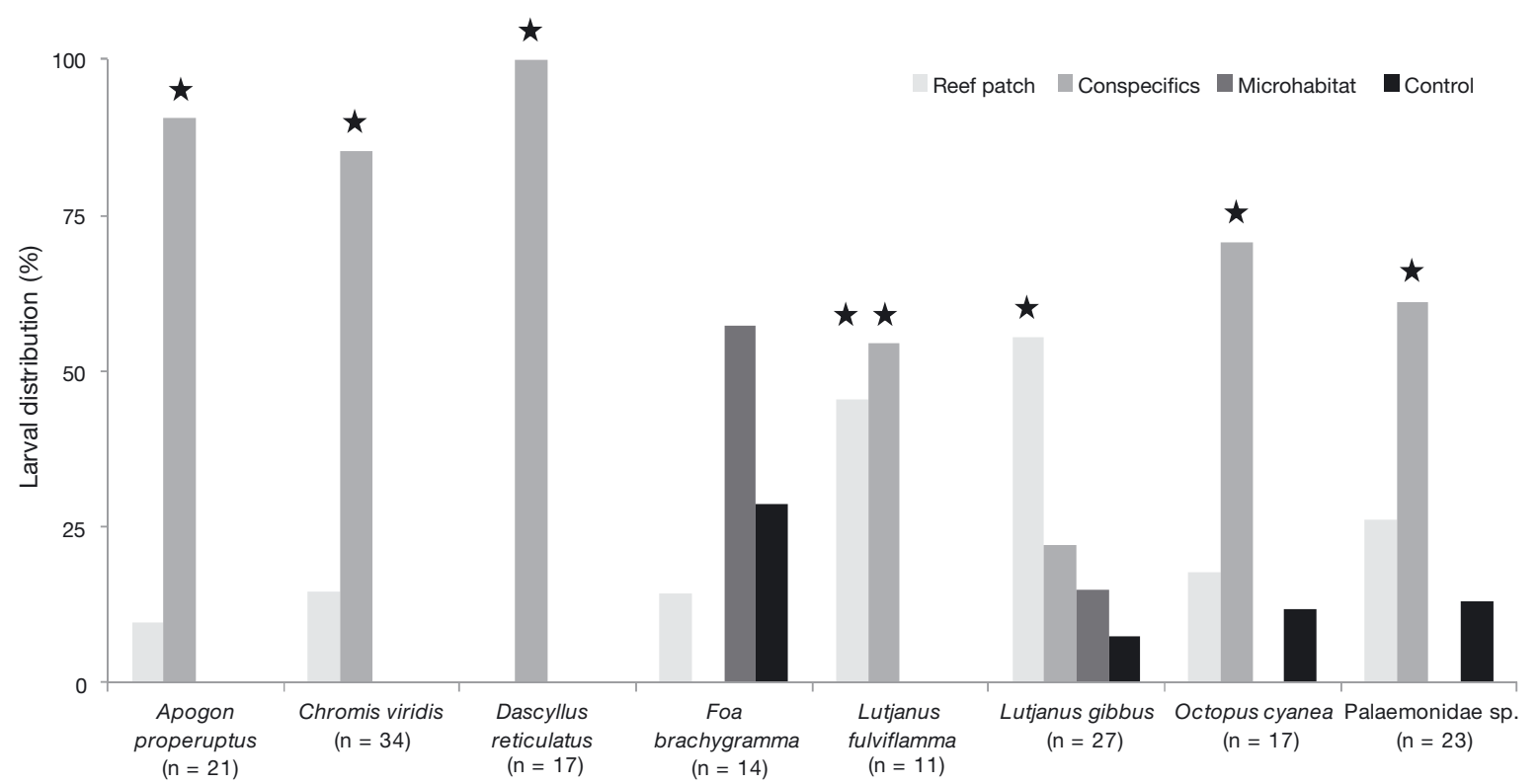

Fig. 3. Larval distribution of the 8 species of coral reef animals among the choice flume to determine their preference among reef patch (reef patch preferred for a given species in Expt 1), conspecifics, microhabitats (live Acropora coral colonies, dead Porites coral colonies with algal turf cover, or seagrass mix), and control water. For all species, the reef patch that was most preferred in Expt 1 was used again in Expt 2, with the exception of Foa brachygramma, where a mix of 2 different reef patch water types (dead coral and seagrass bed patches) was used. Stars indicate that p-values were significant for a given species (larval attraction more toward one microhabitat than toward the control water)

Conspecific water was preferred over the control water by Apogon properuptus $\left(\chi_{1}^{2}=19.0, \mathrm{p}<\right.$ $0.001)$, Chromis viridis $\left(\chi_{1}^{2}=29.0, \mathrm{p}<0.001\right)$, Dascyllus reticulatus $\left(\chi_{1}^{2}=17.0, \mathrm{p}<0.001\right)$, Palaemonidae sp. $\left(\chi_{1}^{2}=7.1, \mathrm{p}=0.007\right)$, and Octopus cyanea $\left(\chi_{1}^{2}=7.1, \mathrm{p}=0.008\right)$. In contrast, Lutjanus gibbus larvae preferred reef patch water (seagrass bed patch) to control water $\left(\chi_{1}^{2}=15.0, \mathrm{p}<0.001\right)$. L. fulviflamma larvae preferred both reef patch water (patch of seagrass bed) and conspecific water to control water $\left(\chi_{1}^{2}=5.0, \mathrm{p}=0.023 ; \chi_{1}^{2}=6.0, \mathrm{p}=\right.$ 0.021 , respectively). 
Table 1. Field observation of newly settled fish at Yoshihara (Ishigaki, Japan). These observations allowed us to record the presence or absence of fish at different reef patches and in the different recruitment microhabitats, as well as whether newly settled fish lived in a school or alone. The aquarium results of Expts 1 and 2 are presented in the last 2 columns. Bold text indicates that a positive result in the aquaria (significant attraction of marine larvae to reef patch or conspecific chemical cues) was related to the field distribution of newly settled fish

\begin{tabular}{|c|c|c|c|c|c|}
\hline \multirow{2}{*}{ Species } & \multicolumn{3}{|c|}{ Field observations } & \multirow{2}{*}{$\begin{array}{c}\text { Expt } 1 \\
\text { Reef patch } \\
\text { preference }\end{array}$} & \multirow{2}{*}{$\begin{array}{c}\text { Expt } 2 \\
\text { Microhabitat } \\
\text { preference }\end{array}$} \\
\hline & Reef patch & Microhabitat & $\begin{array}{l}\text { School } \\
\text { behavior }\end{array}$ & & \\
\hline Apogon properuptus & $\begin{array}{l}\text { Live \& dead coral } \\
\text { patches }\end{array}$ & Dead coral colonies & School & Dead coral patch & Conspecifics \\
\hline Chromis viridis & Live coral patch & Live coral colonies & School & Live coral patch & Conspecifics \\
\hline Dascyllus reticulatus & Live coral patch & Live coral colonies & School & Live coral patch & Conspecifics \\
\hline Foa brachygramma & Dead coral patch & $\begin{array}{l}\text { No specific micro- } \\
\text { habitat }\end{array}$ & Alone & $\begin{array}{l}\text { Dead coral \& seagrass } \\
\text { patches }\end{array}$ & $\begin{array}{l}\text { Dead coral colonies } \\
\text { \& seagrass }\end{array}$ \\
\hline Lutjanus fulviflamma & $\begin{array}{l}\text { Seagrass bed } \\
\text { patch }\end{array}$ & $\begin{array}{l}\text { No specific micro- } \\
\text { habitat }\end{array}$ & School & Seagrass bed patch & $\begin{array}{l}\text { Seagrass bed patch } \\
\text { \& conspecifics }\end{array}$ \\
\hline Lutjanus gibbus & $\begin{array}{l}\text { Seagrass bed } \\
\text { patch }\end{array}$ & $\begin{array}{l}\text { No specific micro- } \\
\text { habitat }\end{array}$ & Alone & Seagrass bed patch & Seagrass bed patch \\
\hline
\end{tabular}

\section{DISCUSSION}

The present study is the first to simultaneously explore the chemical abilities of marine larvae of 3 taxa (fish, crustacean, and cephalopod) and at 2 spatial scales, i.e. reef patches within coral reefs (Expt 1) and microhabitats or conspecifics within reef patches (Expt 2). The aquarium results were related to the observed distribution of newly settled fish in the field (Table 1). For example, visual surveys of fish allowed us to observe Chromis viridis living in a school with conspecifics on live Acropora colonies within the live coral patch. Indeed, $C$. viridis larvae in the aquarium experiments were attracted by the live coral patch (Expt 1) and conspecifics, but not by Acropora colonies (Expt 2). Similarly, the newly settled Lutjanus gibbus lived on the seagrass bed patch without conspecifics, and their larvae were only attracted to the seagrass bed patch water during the aquarium experiments (Table 1).

Although our aquarium results are consistent with field observations, some results for the 4-channel choice flume design should be interpreted with caution (e.g. problems of laminar flow from the source to the downstream compartment, of outer edges with a slower flow rate than the water in the middle channel, and of turbulence and mixing areas). A 2-channel choice flume is widely used for chemosensory cue experiments with a laminar flow in each channel (see Gerlach et al. 2007). In the 4-channel flume, larvae tested were initially present in the downstream end of the compartment where the 4 water types are mixed, then they could move into the laminar water flow of each upstream channel (Fig. 1). In their natural environment, marine larvae are never in a lami- nar flow to detect a habitat or conspecifics (Arvedlund \& Kavanagh 2009). They are always in contact with several chemical cues before selecting 1 odor that they follow to the source (Leis et al. 2011). Therefore, we preferred to use the 4-channel flume instead of a 2-channel flume. Nevertheless, the 4channel flume design should be improved for future experiments to have only 1 central compartment in which the 4 water types are mixed, and to have constant and laminar flow from the source (tank connected to the upstream channel) to the mixing chamber. For example, the 4 channels could be linked together by a central compartment (and not at the 'end' of each channel) in which the 4 water types would be mixed and evacuated by a small hole in the bottom of this compartment.

Successful recruitment on coral reefs by marine larvae necessitates identifying chemical, visual, and/or acoustic cues from islands, reef patches, microhabitats, conspecifics, or predators (Arvedlund \& Kavanagh 2009). However, almost all studies on sensory abilities of fish, crustaceans, and cephalopods have focused on the use of single cue in isolation and at 1 spatial scale (Leis et al. 2011; for exceptions, see Lecchini et al. 2005, Huijbers et al. 2012). Huijbers et al. (2012) tested the response of a fish species (Haemulon flavolineatum) toward auditory, olfactory, and visual cues from 4 different reef patches (seagrass beds, mangroves, rubble, and coral reef). They showed that $H$. flavolineatum only responds to sound from coral reefs and to chemical cues from mangroves and seagrass beds, whereas conspecific visual cues overruled olfactory cues from mangrove and seagrass water. 
Our study is the first to explore a single cue at different spatial scales (reef patch versus microhabitat or conspecifics). Our results show that 3 of the 8 species detected olfactory cues at large spatial scales (reef patch), whereas 6 of the 8 species detected olfactory cues at small spatial scales (conspecifics). Moreover, among the 3 species attracted by the chemical cues of the reef patch water in Expt 1, Lutjanus gibbus still preferred the reef patch chemical cues in Expt 2; Chromis viridis preferred the chemical cues of conspecifics to those of the reef patch, whereas L. fulviflamma preferred both the reef patch water and the conspecific water. Taken together, these results support the results of Huijbers et al. (2012) confirming that multiple sensory cues may enable coral reef animals to distinguish between habitats in a sequential order relevant to spatial scales (island or continental shelf, reef patch, microhabitat, or conspecific). Nevertheless, our results emphasize the importance of conspecific cues above other types of information (reef patch and microhabitat) for habitat selection by coral reef animals. A multitude of other animals also use conspecific information more often than habitat information to find a suitable habitat (Stamps \& Krishnan 2005). Conspecific attraction generally occurs when animals use social cues (or location cues) as positive proximate stimuli during decision-making, including foraging, movement, and recruitment decisions (Danchin et al. 2004). Social aggregation of fish, crustacean, and cephalopod larvae with older conspecifics may be the result of individuals using conspecific 'guides' to potentially find beneficial resources (availability of resources and low mortality; Ben-Tzvi et al. 2009).

To conclude, although it is still not known how fish, crustacean, and cephalopod larvae find their way back to a particular habitat, their differential ability to respond to olfactory stimuli from a reef patch or from conspecifics was clearly implicated in this study. When several cues (reef patch, microhabitat, and conspecifics) were available, marine larvae preferred conspecific cues to reef patch or microhabitat cues. Thus, our results and those of other studies (Danchin et al. 2004, Betts et al. 2008, Fletcher 2009, Huijbers et al. 2012) highlight the need to quantify the relative roles of habitat and social cues in driving patterns of animal distribution.

Acknowledgements. We thank Y. Akita, K. Inoue, K. Kishimoto, T. Miura, Y. Terazono, the Okinawa Prefectural Fisheries and Ocean Research Center, and the International Coral Reef Research and Monitoring Center for assistance with the fieldwork and laboratory experiments. We are also grateful to Crimson Interactive (enago) for the English language review. This study was supported by a grant from the Ministry of Education, Culture, Sports, Science, and Technology of Japan (No. 21780178).

\section{LITERATURE CITED}

Arvedlund M, Kavanagh K (2009) The senses and environmental cues used by marine larvae of fish and decapod crustaceans to find tropical coastal ecosystems. In: Nagelkerken I (ed) Ecological connectivity among tropical coastal ecosystems. Springer, Berlin, p 135-185

Ben-Tzvi O, Kiflawi M, Polak O, Abelson A (2009) The effect of adult aggression on habitat selection by settlers of two coral-dwelling damselfishes. PLoS ONE 4:e5511

Betts MG, Hadley AS, Rodenhouse N, Nocera JJ (2008) Social information trumps vegetation structure in breeding-site selection by a migrant songbird. Proc R Soc Lond B Biol Sci 275:2257-2263

Danchin E, Giraldeau LA, Valone TJ, Wagner RH (2004) Public information: from nosy neighbors to cultural evolution. Science 305:487-491

Devine BM, Munday PL, Jones GP (2012) Rising $\mathrm{CO}_{2}$ concentrations affect settlement behaviour of larval damselfishes. Coral Reefs 31:229-238

> Dixson DL, Jones GP, Munday PL, Planes S and others (2008) Coral reef fish smell leaves to find island homes. Proc R Soc Lond B Biol Sci 275:2831-2839

> Dixson DL, Pratchett MS, Munday PL (2012) Reef fishes innately distinguish predators based on olfactory cues associated with recent prey items rather than individual species. Anim Behav 84:45-51

Doherty PJ (2002) Variable replenishment and the dynamics of reef fish populations. In: Sale PF (ed) Coral reef fishes: dynamics and diversity in a complex ecosystem. Academic Press, San Diego, CA, p 327-358

> Fletcher RJ Jr (2009) Does attraction to conspecifics explain the patch-size effect? An experimental test. Oikos 118: 1139-1147

- Gerlach G, Atema J, Kingsford MJ, Black KP, Miller-Sims V (2007) Smelling home can prevent dispersal of reef fish larvae. Proc Natl Acad Sci USA 104:858-863

Huijbers CM, Mollee EM, Nagelkerken I (2008) Post-larval French grunts (Haemulon flavolineatum) distinguish between seagrass, mangrove and coral reef water: implications for recognition of potential nursery habitats. J Exp Mar Biol Ecol 357:134-139

Huijbers CM, Nagelkerken I, Lossbroek PC, Schulten IE, Seigenthaler A, Holderied MW, Simpson SD (2012) A test of the senses: fish select novel habitats by responding to multiple cues. Ecology 93:46-55

Igulu M, Nagelkerken MI, Fraaije R, van Hintum R, Ligtenberg H, Mgaya YD (2011) The potential role of visual cues for microhabitat selection during the early life phase of a coral reef fish (Lutjanus fulviflamma). J Exp Mar Biol Ecol 401:118-125

> Lecchini D (2011) Visual and chemical cues in habitat selection of sepioid larvae. C R Biol 334:911-915

Lecchini D, Galzin R (2003) Influence of pelagic and benthic, biotic and abiotic, stochastic and deterministic processes on the dynamics of auto-recruitment of coral reef fish. Cybium 27:167-184

Lecchini D, Planes S, Galzin R (2005) Experimental assessment of sensory modalities of coral-reef fish larvae in the 
recognition of settlement habitat. Behav Ecol Sociobiol 58:18-26

Lecchini D, Polti S, Nakamura Y, Mosconi P, Tsuchiya M, Remoissenet G, Planes S (2006) New perspectives on aquarium fish trade. Fish Sci 72:40-47

Lecchini D, Osenberg CWO, Shima JS, St Mary C, Galzin R (2007) Ontogenetic changes in habitat selection during settlement in a coral reef fish: ecological determinants and sensory mechanisms. Coral Reefs 26:423-432

Lecchini D, Mills SC, Brié C, Maurin R, Banaigs B (2010) Ecological determinants and sensory mechanisms in habitat selection of crustacean larvae. Behav Ecol 21: 599-607

Lecchini D, Waqalevu VP, Parmentier E, Radford CA, Banaigs B (2013) Fish larvae prefer coral over algal water cues: implications of coral reef degradation. Mar Ecol Prog Ser 475:303-307

Leis JM, Carson-Ewart BM (2003) Orientation of pelagic larvae of coral-reef fishes in the ocean. Mar Ecol Prog Ser 252:239-253

Leis JM, Siebeck U, Dixson DL (2011) How Nemo finds home: the neuroecology of dispersal and of population connectivity in larvae of marine fishes. Integr Comp Biol 51:826-843

Editorial responsibility: Alberto Acosta,

Bogotá, Colombia
Montgomery JC, Jeffs A, Simpson SD, Meekan M, Tindle C (2006) Sound as an orientation cue for the pelagic larvae of reef fishes and decapod crustaceans. Adv Mar Biol 51:143-196

Munday PL, Dixson DL, Donelson JM, Jones GP, Pratchett MS, Devitsin GV, Døving KB (2009) Ocean acidification impairs olfactory discrimination and homing ability of a marine fish. Proc Natl Acad Sci USA 106: 1848-1852

Nakamura Y, Shibuno T, Lecchini D, Kawamura T, Watanabe Y (2009a) Spatial variability in habitat associations of pre- and post-settlement stages of coral reef fishes at Ishigaki Island, Japan. Mar Biol 156:2413-2419

Nakamura Y, Shibuno T, Lecchini D, Watanabe Y (2009b) Habitat selection by emperor fish larvae. Aquat Biol 6: 61-65

> Stamps J, Krishnan VV (2005) Nonintuitive cue use in habitat selection. Ecology 86:2860-2867

Stanley JA, Radford CA, Jeffs AG (2012) Location, location, location: finding a suitable home among the noise. Proc $\mathrm{R}$ Soc Lond B Biol Sci 279:3622-3631

Tolimieri N, Haine O, Jeffs A, McCauley RD, Montgomery JC (2004) Directional orientation of pomacentrid larvae to ambient reef sound. Coral Reefs 23:184-191

Submitted: March 19, 2013; Accepted: August 26, 2013 Proofs received from author(s): October 2, 2013 